\title{
MISTRAL MISTRAL
}

Journal of Latin American Women's

Intellectual \& Cultural History

\section{Infancias monstruosas: Debimos ser felices, de Rafaela Lahore, y Mugre rosa, de Fernanda Trías}

\author{
Lorena Amaro, Pontificia Universidad Católica de Chile
}

To cite this article: Lorena Amaro. 2021. "Infancias monstruosas: Debimos ser felices, de Rafaela Lahore, y Mugre rosa, de Fernanda Trías.” Mistral: Journal of Latin American Women's Intellectual \& Cultural History 1 (2): 2034, https://doi.org/10.21827/mistral.2.38026

\begin{abstract}
The following article analyzes the novels Debimos ser Felices, by Rafaela Lahore and Mugre rosa, by Fernanda Trías, both published in 2020. While Lahore works her way through remembrance in an intimate, fragmentary, autobiographical way, Trías' narrative is complex, apocalyptic, and dystopic. It ranges from a progressive uncertainty about the present to memory's capacity to hang on to family affections. However, they converge in their narratives' subtle, dreamlike atmospheres that focus on the voice of children fluctuating between abnormality and monstrosity. Their reflections emphasize the reconstruction of their respective genealogies through reminiscence.
\end{abstract}

\section{Keywords}

Childhood; Monstrosity; Genealogy; Memory; Dystopia

\section{Resumen}

El siguiente artículo analiza las novelas Debimos ser felices, de Rafaela Lahore, y Mugre rosa, de Fernanda Trías, ambas publicadas en 2020. Si bien comparten ciertas atmósferas sutiles, casi oníricas, Lahore trabaja el recuerdo de manera íntima, fragmentaria y autobiográfica, mientras que la narración de Trías se proyecta como una compleja novela apocalíptica, distópica, que oscila entre la progresiva incertidumbre del presente y la capacidad del recuerdo para aferrarse a los afectos familiares. Ambas ponen en el centro de sus reflexiones a niños y niñas que transitan entre la anomalía y la monstruosidad, con un fuerte acento en la reconstrucción memoriosa de sus respectivas genealogías.

\section{Palabras clave}

Infancia; Monstruosidad; Genealogía; Memoria; Distopía 


\title{
Infancias monstruosas: Debimos ser felices, de Rafaela Lahore, y Mugre rosa, de Fernanda Trías ${ }^{1}$
}

\author{
Lorena Amaro, Pontificia Universidad Católica de Chile
}

¿Hay alguna infancia que no se cuente o rememore como una anomalía, producto ya sea del ensueño, de la soledad, de la opacidad del recuerdo o de la monstruosidad social que supone la experiencia de una vida aún no normalizada? En un ensayo sobre infancia y biopolítica, Eduardo Bustelo utiliza el concepto de "infancia sacer" (en alusión al homo sacer en el texto Infancia e historia, de Giorgio Agamben) para señalar precisamente cómo la infancia es construida como zoé, que en el pensamiento griego es la vida "pura" y no la vida biológica y cronológica, aquella que se ordena de acuerdo al lenguaje y la norma social. Esta asociación biopolítica con la nuda vida despoja "todo lo humano de los humanos" (24), lo que fragiliza la infancia y la despoja de valor político (Bustelo 27), al tiempo que la expone a los grandes problemas contemporáneos, como la esclavitud, la brutal migración infantil, el tráfico de cuerpos y órganos, la criminalización de la infancia en condiciones de pobreza y su "minorización" por parte de las políticas públicas. La condición de lo monstruoso exacerba, en la construcción de las imágenes de infancia, este margen de la política y la ciudadanía, reclamando para estas figuras un foco de atención y discusión.

Dos títulos de escritoras uruguayas, publicados coincidentemente en $2020^{2}$, ofrecen un punto de partida para incursionar en este panorama. Ambas abordan la infancia con gran sutileza estética: Rafaela Lahore en Debimos ser felices, y Fernanda Trías en Mugre rosa. Las dos esbozan infancias signadas por la enfermedad y lo monstruoso, produciendo relatos dobles que llevan a sus narradoras a referirse a sus propias infancias, pero también a la de alguien más, y, finalmente, ambas proponen, por lo mismo, relatos genealógicos, en que la infancia cobra sentido a partir de potentes historias materno-filiales. En ambos casos, la narración se instala, a través de la rememoración, en eventos traumáticos que se presentizan a través del relato. Como propone María José Punte - parafraseando a Foucault y la lectura que de él hace Teresa de Lauretis a propósito del género-, se evidencian aquí las "tecnologías" o procesos de representación de la infancia, incomprendida por los adultos: un afuera monstruoso que les devuelve como espejo la inteligibilidad de sus propios límites, de lo que está definido y normado. Y, al mismo tiempo, un afuera incomprendido, al que solo se puede acceder a través de fragmentos, esquirlas de experiencias rememoradas por su muchas veces enigmática intensidad.

\footnotetext{
${ }^{1}$ Este texto forma parte de los resultados del proyecto CCA 2020-65087215 “Contemporáneas: Conversaciones con narradoras hispanoamericanas (después del tsunami)”, financiado por la Dirección de Artes y Cultura de la Vicerrectoría de Investigación, Pontificia Universidad Católica de Chile, y de los proyectos FONDECYT Regular 1180522, "Carto(corpografías): narradoras hispanoamericanas del siglo XXI" y Anillos SOC180023 (ANID) "The Production of the Gender Norm".

${ }^{2}$ Ambos fueron nominados al Premio Bartolomé Hidalgo, de la Cámara del Libro de Uruguay, que ganó finalmente Mugre rosa, novela que también le ha valido a Trías el Premio Sor Juana Inés de la Cruz en México. Debimos ser felices también ha tenido importantes reconocimientos: el Premio Mejores Obras Literarias (categoría inédita) otorgado por el Ministerio de las Culturas en Chile y la nominación como finalista, al cierre de esta revista, al Premio Municipal de Literatura de Santiago, en la categoría novela.
} 
Los puntos de partida para estas dos novelas, como sus estéticas, son sin embargo muy distintos: la narradora del relato fantástico de Trías vive un presente distópico que cada vez más autorxs latinoamericanxs comienzan a frecuentar (Schweblin, Enriquez, Castagnet, entre otros). Aparecida bajo pandemia, la novela ha sido leída principalmente en relación con el COVID-19 y la crisis planetaria, que pone en evidencia la fragilidad de los cuerpos en tiempos de necropolítica neoliberal, y también, específicamente, de los países del sur global, dependientes en su mayoría de laboratorios lejos de sus fronteras. En el libro de Lahore nos encontramos, por el contrario, con una estética cotidiana y un montaje autobiográfico, fragmentario e íntimo, más cercano a lo que en el Cono Sur se viene llamando "narrativa de los hijos", si bien aquí el relato familiar apenas remite al contexto político y social en que se desarrolla, para dejar registro de una vida de frontera (entre Uruguay y Brasil) en que los trazos de la dictadura uruguaya (1973-1985) son difuminados, pero están latentes en las violencias que enfrentan principalmente las mujeres de esta historia.

Tanto en la novela de Trías como en la de Lahore hay niños y niñas, ya sea afectadxs por la violencia intrafamiliar, por el abandono o por enfermedades que provocan su señalamiento y discriminación. La enfermedad, lo "patológico", se revela como "anormal" en una intrincada red de asociaciones por las que se llega incluso a juicios morales, a la culpa y al castigo. Estxs niñxs son "lo otro", aquello que una sociedad patriarcal, afincada en deseos no solo normalizadores, sino también exitistas, arrasa y destruye. El repliegue de la infancia deja una marca en las orillas de la adultez, una espuma que reverbera con el recuerdo.

\section{Detener el futuro}

El espacio descrito en Mugre rosa es entrópico: su protagonista, proveniente de una clase media profesional, ha ido resignándose a un lento apocalipsis, propiciado por repentinos vientos asesinos, que despellejan a las personas. En conexión con este fenómeno, las costas están infestadas de unas algas rosáceas, los peces han muerto y la población es alimentada masivamente con "mugre rosa", carne tratada en una fábrica orwelliana. En este contexto, ella, que es quien también narra la historia, ha decidido no huir hacia las ciudades "del interior", como lo han hecho otros, porque Max, su ex marido, a quien conoce desde los cinco años, se encuentra internado en el "Clínicas", donde lo tratan como "crónico", esto es, alguien que ha estado expuesto al "viento rojo", pero no ha muerto (y se da a entender que experimentan con su cuerpo).

Hay otros dos personajes en la órbita de la narradora: su madre, quien está esperando a que ella junte dinero para marcharse a Brasil, y Mauro, niño que padece el síndrome de Prader-Willi, que le impide dejar de comer. La narradora es cuidadora de este niño; ha dejado un trabajo profesional para dedicarse a este oficio que su madre no aprueba. Los padres del niño han huido al interior para guarecerse del viento rojo y la devastación; ellos periódicamente se lo llevan a la ciudad, para que lo someta a una dieta y a ejercicios de los que sus padres prefieren no hacerse cargo. Entre los distintos capítulos de este relato nos encontramos con breves y delirantes diálogos, voces que aparecen y desaparecen, sin aparente continuidad, más que la que se puede hallar sobre todo en la relación entre la narradora/protagonista y Max.

Mauro evidencia en su cuerpo los signos de una infancia anómala o "queer", término que María José Punte recoge de Kathryn Bond Stockton para analizar una serie de relatos que se interrogan sobre la infancia y los límites biopolíticos. El síndrome que el niño padece 
lo lleva al extremo del autocanibalismo y el vampirismo y en su cuerpo la protagonista avizora en todo momento un despojo, una cáscara que acabará por romperse para que reine el síndrome, el padecimiento:

A veces me preguntaba si de verdad podría llegar a tanto, a comerse sus propios dedos, a beber su propia sangre. ¿Qué haría el síndrome abandonado a sí mismo? El cerebro de Mauro nunca diría basta. Huevos podridos, hongos, cal; podría comer hasta ahogarse, hasta desgarrar el esófago como un trozo de tela vieja. (128)

El salvaje deseo siempre insatisfecho de este niño en un tiempo de carestía y destrucción, detona en la protagonista una serie de recuerdos sobre su propia infancia, marcada por la ausencia o indiferencia de su mamá y la necesidad de afecto, que acaba por prodigarle una empleada, Delfa, su verdadera y secreta madre. Max, por su parte, es la presencia viva, casi en ruinas, no solo de un matrimonio, sino también de la infancia compartida por ambos. Su lealtad hacia el ex marido, que le impide irse de la ciudad para poder seguir visitándolo en el hospital, se basa, de hecho, en las experiencias de infancia: "Vivíamos para honrar a los niños que habíamos sido y que ya ni siquiera se parecían a nosotros" (69).

Las escenas recordadas, relacionadas con estos dos ámbitos -la maternidad y la infancia propia-, revelan el deseante trayecto afectivo de la narradora. La construcción silábica del código onomástico de la novela no es indiferente a todo esto: Madre, Mauro, Max (ma-ma) conforman un circuito del hambre, donde debiera haber, no obstante, vínculos nutricios. Es en la relación con todxs ellxs que la protagonista se va descubriendo a sí misma, no solo como hija de una madre sustituta, sino también como madre de Mauro, a quien finalmente debe renunciar.

Mención aparte merece el personaje de este niño, quien presenta un cuadro extremo y siniestro del síndrome de Prader-Willi, ${ }^{3}$ para encarnar una abyección y animalidad "monstruosas":

... desperté a mitad de la noche con un ruido de ratones. La luz de la cocina estaba prendida y desde el umbral vi a Mauro en calzoncillos, la bolsa destrozada a su alrededor, mientras revisaba la basura y se llevaba a la boca todos los desperdicios que encontraba, comestibles o no. (26)

Su tamaño no se correspondía con su lenguaje corporal. Parecía un niño inflado a la fuerza, inflado como una llanta que no puede ceder un milímetro más de caucho, los cachetes rechonchos, un ojo que se le cerraba a media asta y la boca diminuta, pero capaz de abrirse para devorar cualquier cosa que tuviera enfrente sin siquiera masticarla. Una boquita de piraña, rápida e imparable. (59)

Ella volvió a la cocina y lo encontró comiéndose un pollo congelado, recién sacado del frizer. Mauro masticaba el mazacote de piel blanca y granulosa, cubierto de escarcha, y ni siquiera la oyó entrar. (71-72)

\footnotetext{
${ }^{3}$ En la novela no se explicita el nombre del síndrome, que es aludido en varias oportunidades como una entidad con características prácticamente humanas. Sí es mencionado literalmente en las entrevistas realizadas a la autora con motivo de la aparición del libro, como la que hace Camila Osorio en el diario El País (v. Bibliografia).
} 
La ajenidad de Mauro traspone los límites de lo humano, pero incluso de lo viviente: le cede su lugar al síndrome, a la enfermedad, a una falla de la información genética. El niño ya no es el niño, en su sitio hay una enfermedad, un cuadro médico, pero sobre todo, un apetito oscuro e inexplicable, una carencia incesante que provoca múltiples efectos no solo en la vida del propio Mauro, sino también a su alrededor:

Con Mauro no podía hablar mucho, y eso alteraba la ecuación. Me sentía torpe y desarmada. Al principio, cuando recién lo conocí, no podía pensar en él como algo distinto de su enfermedad. Su condición de niño enfermo lo definía y no le daba derecho a ser otra cosa. (69)

Con el tiempo empecé a pensar en su síndrome como un impostor que le había tomado el cuerpo. Ni siquiera era un gen que dominaba su hambre, sino la ausencia de uno, un pedacito de información faltante en el cromosoma quince, la niña bonita. A primera vista había sido un bebé como los otros, solo que sin fuerza para succionar, los músculos laxos, la cabeza floja. Un futuro monstruo, incapaz de saciarse. (71)

Es esta ausencia, y no un exceso, la que crea al "monstruo", en una interesante ecuación de resta, primero, y luego multiplicación, que amenaza la vida misma de la narradora, quien ya ha descendido socialmente por cuidar a Mauro, y se expone a la muerte por él y por el afecto de Max: "Tenía la impresión de que podía quebrarme en tantos pedazos que sería imposible reconstruirme, que mis encías sangrantes dejarían de sostener los dientes" (119). El detalle de la boca de ella es importante: a diferencia de Mauro, apenas puede alimentarse para cuidarlo a él, y en diversos momentos menciona que le sangran las encías, componiendo así una imagen vampírica (una madre castradora), pero también una carencia, la imposibilidad de alimentarse, precisamente en un relato que vincula exterminio, comida, nutrición (también afectiva) y hambre.

La novela describe un presente distópico en que la comida es sometida a un proceso de producción a gran escala, lo que tiene como resultado la "mugre rosa" -"olía a sangre coagulada y al líquido que Delfa usaba para lavar el baño" (49) - una carne prensada de dudosa calidad o aporte nutritivo, pero que es el visado para la supervivencia en un mundo incierto. Mauro tiene hambre en un mundo en que la comida escasea y en que la manera de saciarse es a través de este dudoso sustituto alimenticio, como si la propia carne sufriera de un síndrome, de su propia carencia que la hace monstruosa. Este carácter tiene, también, una imagen que asocia la "mugre rosa" con la infancia:

Así nacemos: un coágulo de carne, boqueando por un poco de oxígeno; una bola de mugre rosa que, una vez expulsada, ya no tiene más remedio que aglutinarse a ese otro cuerpo, el de la madre, morder con fuerza la teta de la vida. Pero no. Soy injusta. No todos los hijos odian la mano que los protege y les abre heridas en la piel. Los hay que no. Conocí a muchos. Y así supongo que también habría quienes adoraran la procesadora nacional, quienes sintieran orgullo y le perdonaran todo. (113)

La vacilante relación de la narradora con la maternidad se va definiendo a lo largo del relato. ${ }^{4}$ Se trata de un personaje que va creciendo en su papel de cuidadora, aunque desde un principio

\footnotetext{
${ }^{4}$ Hay líneas de continuidad bastante evidentes con La azotea (2001), novela anterior de Trías, que transcurre en el espacio cerrado de un departamento y en que se insinúa una relación incestuosa entre padre e hija. La
} 
le ofrece a Mauro el único alimento que sus padres le niegan sistemáticamente: el lenguaje. En el campo, el niño queda abandonado a su suerte, con absoluta libertad para empacharse, pero nadie le ofrece este otro alimento: "Yo sospechaba que allá nadie le hablaba, que lo tenían como un animalito rampante, dando vueltas al aire libre, metiendo la mano en cualquier hueco lleno de bichos" (77). Sin lenguaje, sin cariño o contención, los límites de lo humano se difuminan. Es solo la madre suplente (hija de otra madre suplente) quien conversa con él, lo escudriña, le cuenta historias y juega con él, buscando ir más allá del síndrome "impostor", para sacar a la luz al "verdadero" Mauro:

Me pagaban por eso también. Por adelgazar y cederle mi cuerpo a Mauro. ¿A Mauro o al síndrome? No solo habían comprado mi tiempo sino también mi energía; habían comprado mis músculos, mis cuádriceps doloridos y mis brazos temblorosos de tanto levantar a Mauro para hamacarlo en el juego del helicóptero. Vivía para el síndrome, buscando agotar a ese animal insaciable y acceder, acaso por un momento, al verdadero Mauro, el que estaba detrás del hambre. Cuando el síndrome no podía más, cuando caía rendido, oliendo a sudor rancio y a manos que se habían arrastrado por todo el edificio, yo había cumplido mi trabajo. (89)

Este "trabajo" de amor es presentado, sobre todo al principio, como un trabajo peligroso. Esto se explicita por ejemplo en la curiosidad del chofer que le lleva al niño y la paga del mes, quien se queda esperando a que ella abra el sobre del sueldo: "Supongo que le daba curiosidad saber cuánta plata había que ofrecerle a alguien para que aceptara hacerse cargo de un niño que no distinguía entre un dedo y una morcilla" (58). Este peligro concreto, de ser literalmente "devorada", se va transformando a lo largo de la narración, en otro peligro no menos deshumanizador: "Mi trabajo consistía en eso, en verlo engordar y finalmente (¿cuándo?) verlo morirse, sin el dolor de las madres”. (128)

Como se ha planteado, a mayor desarrollo de la historia, más intenso se torna el apego entre el niño y ella. En un mundo distópico, la protagonista logra sostenerse en virtud de los afectos que siente por Max y su madre (a pesar del resentimiento hacia esta última), pero sobre todo por el amor del niño, al que logra conquistar. Sin embargo, sufre un revés final, cuando la madre de Mauro se presenta para llevárselo definitivamente al campo: "Me pagaban para que, cuando llegara ese día, lo dejara ir" (262). La narradora se ha concentrado hasta un punto inaudito en el bienestar del niño, en la cotidianidad imposible de la lucha con su apetito, abandonándose, pero al mismo tiempo consciente de que ya prácticamente lo único que la une a la vida es la responsabilidad que tiene con él -"De pronto, ya no tenía derecho a arriesgar mi vida" (227)-:

Días sin pensar en mi madre ni en Max. La vida enfocada como un embudo en Mauro, en su estómago, en sus quejidos nocturnos. Ahora sentía el cansancio como un absceso, un dolor encapsulado y lleno de pus que no encontraría alivio excepto mediante un tajo. No había espacio para nada más. No tenía un plan alternativo y una parte de mí imaginó que así sería la nueva vida. ¿Por qué no? Sitiados por las algas, hundidos en un pantano de niebla. (207)

presencia de una niña pequeña en este lugar, el triángulo afectivo y de cuidados al que se aferra la protagonista, así como el movimiento de los personajes que están "fuera", configuran una atmósfera cerrada, enrarecida y monstruosa, similar a la de Mugre rosa. 
Es esta relación con Mauro -una relación construida en un entorno hostil, de permanente niebla, vientos, falta de claridad, como si el mundo de la novela estuviera fraguándose en una matriz- la que paulatinamente va despertando en ella recuerdos de infancia de su propia madre sustituta, Delfa. Una empleada a la que ella ha escogido muy conscientemente como madre: "Por esa época, yo había empezado a llamar a Delfa 'mamá'. Lo hacía a espaldas de mi madre, sin inocencia infantil, sabiendo que se trataba de la peor de las traiciones" (67). Es una madre secreta, a la que toca a "escondidas", solo cuando la madre biológica sale: "Cómo me hablaba Delfa, cómo le hablaba yo. Le daba besos en las manos, y las manos me peinaban, gruesas, pesadas, la sensación de ese peso sobre mi cabeza me anclaba al presente. El cuerpo era nuestro secreto" (172). El cuerpo es el significante que como ningún otro puede unir a una madre y un hijo o hija y es también el cuerpo, aunque sea en una lucha exasperada, el que irá uniendo a la narradora y a Mauro.

Es precisamente en el bregar cotidiano con el síndrome del niño, que ella recuerda fragmentariamente los cuidados de su madre sustituta, y vuelve a sus manos: "Las labores de cuidado de ese niño la hacen pesar en Delfa. "Esa noche había soñado con ella, y pensé que Delfa hubiera sabido cómo despercudirse ropa blanca, quitar manchas difíciles" (65). "Ahora pienso: las manos de Delfa eran otra certeza (...) y no había nada que yo ansiara más que eso, lo predecible de las cosas" (66). La narradora se arropa en estos recuerdos, "dando vueltas en la calesita del pasado, arrebujada en la memoria como en un sillón demasiado blando" (46), como le enrostra Max.

A lo que remontan estos recuerdos es a un comienzo, en una novela en que es difícil discernir cuándo empezó la catástrofe, asunto al que la narradora parece conferirle cierta importancia: "Si voy a contar esta historia debería empezar por algún lado, elegir un comienzo. ¿Pero cuál? Nunca fui buena para los comienzos” (13); "El comienzo nunca es el comienzo. Lo que confundimos con el comienzo es solo el momento en que entendemos que las cosas han cambiado" (45). Tal vez de aquí la necesidad de remontarse a los veraneos infantiles en la playa, la relación con Max, el día en que siendo niños tapiaron una cueva para matar a un perro. ¿Cuál es el comienzo del fin? ¿Se puede volver a la infancia, entender su lengua?

Entre los capítulos de la novela se intercalan diálogos, voces que no están localizadas, que incluso podrían ser monólogos. Aparecen fuera de contexto: ¿Max y la narradora, que conversan? Estos diálogos fragmentarios son deliberadamente ambiguos y abiertos; uno de ellos configura un paisaje, un horizonte que parece representar la memoria de la infancia:

Sería como un museo.

¿Qué tipo de museo?

Un museo de cosas perdidas.

¿Y qué habría?

Sombrillas de lona, esos kits de playa que venían

envueltos en una red.

El rastrillo.

Moldes de estrellas de mar.

Hay cosas que no podrían mostrarse.

El olor a Hawaiian Tropic.

Los pelitos blancos en los brazos, tiesos de sal.

¿Y qué sería lo peor?

Las picaduras de los tábanos.

Eso no es lo peor. 
El olor a lobo muerto.

¿Y lo mejor? (167)

La intensidad sensorial que combina olores, tactos, imágenes infantiles, convoca desde lo luminoso a lo siniestro. El "lobo muerto" forma parte de un conjunto isotópico habitado por el perro de la playa, la mugre rosa, los peces muertos y otros registros que anudan la crueldad y la muerte experimentadas en la infancia con la experiencia apocalíptica del viento rojo y los desollados que va dejando a su paso. ¿La explicación está en la infancia? Hay muchas razones para volver a ella.

La narradora no logra tener una lengua común con su madre biológica, ambas parecen hablar una media lengua, así como Mauro habla una media lengua e incluso una lengua inventada: "Ni siquiera eran palabras conocidas; había vuelto a refugiarse en su lenguaje inventado, con vocales como lamentos" (77). Siendo una profesional que trabaja en el ámbito de la escritura (una agencia, donde edita una revista llamada, irónicamente, "Bien-Estar"), ha renunciado a ello para regresar a la niñez, en una profunda identificación con el niño que cuida. Esta identificación va más allá de la experiencia de infancia perdida y rememorada: se vincula, más bien, con la monstruosidad. Por alguna razón, la narradora ha configurado su propia historia infantil desde ese lugar. ¿Es un monstruo, acaso, debido a la repentina muerte de Delfa, o por la falta de cariño materno, o por el extraño desapego y la ironía constante de Max? ¿Porque siente culpa? ¿Es culpa por haber hecho de Delfa su madre secreta, o por no haber estado con ella cuando murió?

En tanto Mauro es un "monstruo" por su genética, ella es ese otro tipo de monstruo tan caro al discurso jurídico que analiza Foucault, el monstruo moral. La expresión figurada de esta la hallamos en una alucinación que tuvo Max al ingerir hierbas medicinales. En este "viaje", él ha creído ver el rostro de ella cuando niña, pero no el de todos los días, sino uno en particular: la cara que ella puso cuando él le dio el primer beso, siendo aún muy pequeños. En su alucinación, Max, que comparte con ella la historia del perro asesinado, observa una serpiente que abre la boca y por ahí asoma algo:

—Un feto le salía por la boca — dijo—, y yo sabía que el nacimiento la estaba matando. Lo que salió de la serpiente fue una mujer que tenía mi cara, aquella cara de la infancia que él había visto, pero que al mismo tiempo era un monstruo.

—Vos sos el envoltorio — dijo—, pero abajo hay otra cosa. Abajo está esa cara. Una niña disfrazada de monstruo.

— ¿O un monstruo disfrazado de niña?

— ¿Importa? - dijo.

- A mí sí me importa.

-El monstruo y la niña eran la misma cosa. (101)

Será mucho después que termine de fraguarse la analogía entre ella, Mauro, lo monstruoso, cuando derrotada por los irrefrenables acontecimientos ella se examine y descubra, como cuando antes lo descubrió en el niño, a una especie de suplantador:

Y había vuelto a sentir la presencia del ser defectuoso que vivía en mí, una boca negra que se abría y se cerraba. Por momentos pensaba que el ser defectuoso y yo éramos la misma cosa; otras veces lo veía como a un parásito que quería suplantarme. La boca negra hablaba, decía que yo era una inservible, siempre hundida en el caldo tibio y aguachento de mi vida. (229) 
De la alucinación a la metáfora, esta revelación acontece en un fuera del tiempo, como una suerte de verdad inamovible, que contrasta con otros aspectos temporales de la novela que conviene revisar.

Además del presente distópico, en la novela confluyen otros tiempos: el de la memoria, por ejemplo, que la protagonista percibe como una "vasija rota": "mil pedazos y lascas de barro seco. ¿Qué partes tuyas quedan intactas? El barro te hace resbalar, perdés el equilibrio. Y era un equilibrio tan precario, te esforzaste tanto en mantenerlo, para luego irte de culo al piso. Qué risa. Mirate. No hay manera grácil de caer”. (169) El tiempo de la rememoración es el de las culpas y las frustraciones infantiles no resueltas. Mauro es el recordatorio de esa caída que no cesa. Pero él es también portador de otra temporalidad: la de la infancia y el juego. Su inocente forma de estar en el mundo le da la idea, a ella, de un "eterno presente, un aquí y ahora hecho de hambre y anhelo" (199). Y, finalmente, está el tiempo temido del futuro: "Qué sería de Mauro si me pasaba algo a mí (...). El pensamiento me abría un hueco de terror en el cuerpo" (227). Las figuraciones del horror se multiplican: un taxista le cuenta que una mujer se arrojó de un edificio y que se llevó con ella a un niño de la edad de Mauro (250). ¿Es posible resistir al fin del mundo? Es algo que ella se pregunta, en continuidad con su meditación sobre los comienzos: “¿Es así como terminan las cosas? Un final es solo la constatación de que algo más ha empezado. Yo me resistía a ver ese nuevo principio, como me había resistido a todos los principios, desde siempre”. (230) Lo más doloroso de este final será la pérdida irremisible de Mauro: "El cuerpo de Mauro seguirá creciendo, pero el resto permanecerá igual (...) Aprenderá algunas palabras nuevas, variaciones de juegos. ¿Pero cuántos años o meses le durará mi recuerdo? ¿Sentirá una pérdida, por mínima que sea, como quien repasa con la lengua el hueco de un diente caído?" (273). Lo que no se puede detener, concluye, es "un futuro que ya está aquí" (276), el futuro apocalíptico en que sin querer verlo, han estado habitando los personajes de esta historia desde un momento indefinido y que es, también, desde donde emerge la voz anónima de la narradora, como si fuera el último ser humano que habita el mundo.

\section{La familia del Minotauro}

El libro de Lahore, con tantos nexos y a la vez tan diferente en su estética al de Fernanda Trías, está orientado principalmente hacia el pasado y, solo hacia el final, a un presente de aceptación y reconciliación con el tiempo recordado. Revela desde sus primeras páginas los secretos familiares que se suelen esconder: el primero, que la madre ha estado tentada por la idea del suicidio desde muy joven y el segundo, un incesto de los abuelos de la narradora, quienes se casaron siendo primos hermanos. Ella lidia con estas situaciones en el presente, cuando ya se ha independizado de su madre y sus abuelos están muertos, en un relato que va engarzando su propia infancia con la de su madre. Utiliza una voz en la que se percibe cierto distanciamiento, a causa de la transformación social experimentada por esta familia: quien narra es una profesional criada en la ciudad y lo que cuenta de sus abuelos campesinos ancla sus raíces en un lugar lejano física y temporalmente, como si se tratara, en clave benjaminiana, del relato de un cuento tradicional (Benjamin 2008).

La infancia de la madre transcurre en el campo y está llena de detalles significativos: la presencia de la yegua Cumparsita, el perro Cuidado, el día en que jugando con su padre a dar tiros al blanco mata a un benteveo. La narradora relata esos recuerdos ajenos como al 
igual que los suyos propios, como en voz baja: muchas imágenes fragmentarias, reuerdos fundados sobre todo en lo sensorial y marcados por la mirada infantil. Esta niña urbana recuerda la primera vez que acarició a un gato, a su tortuga Miguel Ángel en una caja, las figuras que formaban las manchas de humedad en la pared. Imágenes en que ciertamente predomina una fusión de lo humano y lo no humano y que van configurando un espaciotiempo originario, casi bíblico.

Con esta atmósfera, la narradora da cuerpo a un doble relato: el de su infancia con una madre deprimida, de tendencias suicidas, que un día incluso pensó en arrojarse con ella, niña, a un ómnibus; y el de la infancia materna, que a modo de pesquisa freudiana pareciera querer indagar en el origen de un trauma, aquello desusado que deviene acontecimiento, un evento de excepcional intensidad e impacto, cuyo rastro se proyecta en el presente.

En las primeras páginas del libro hallamos una pista de este posible evento: "Si la historia tuviera un comienzo, podría ser éste: mi abuela que se casó con Amantino el 20 de julio de 1946 (...) Ella tenía 23 años cuando se casó con Amantino, su primo hermano” (11). Como antes Trías en su relato distópico, en este caso hay también una reflexión sobre los comienzos: ¿qué hay en el origen, cuándo hay un origen? Pero a diferencia de las deliberadas incertidumbres y vacilaciones de la narración que dan forma a Mugre rosa, aquí hallamos una escena originaria precisa, transmitida a través de generaciones como un punto de inflexión, como una fatalidad: "Mi abuela siempre repitió que esa lluvia, la que caía mientras se casaba con el único hombre de su vida, había sido un mal augurio" (12). La historia se recubre de relato maravilloso; un fatuum oscuro se desata sobre la familia, al menos en la narración construida por esta abuela.

Pero si se observa con atención el texto, más allá de lo que éste propone como un origen (el desafortunado matrimonio entre primos), lo que deja surcos profundos en la genealogía familiar es la violencia. Los eventos violentos han sucedido "antes de que yo naciera" (9), como las notas de suicidio de la madre de la narradora, que ocurren en ese "antes", o la amenaza del abuelo celópata, de dispararle a la abuela. La brutalidad se remonta incluso más atrás, a la fundación de Rivera, ciudad fronteriza ubicada en el límite con Brasil y de la que es oriunda esta familia, llamada así en honor a un genocida de la población charrúa. Violencias coloniales y patriarcales que se encarnan en Amantino, el abuelo, y su dominio sobre la esposa y los tres hijos, a quienes maltrata simbólica y psicológicamente, llevando la vida familiar a límites invivibles. De los celos al intento de suicidio (que lo lleva a pasar unos meses en una institución psiquiátrica), Amantino se presenta como una figura trágica, a la que la narradora nunca llegó a conocer ni a llamar abuelo, por lo que "las pocas veces que necesité nombrarlo lo llamé por su nombre, como si fuera un personaje histórico, un extranjero o un enemigo" (65). Una figura distante, construida a partir de sus paranoias, de sus desbordes e impulsos devastadores: "Amantino dormía con un revólver bajo la almohada, un Smith and Wesson calibre 38. Lo utilizó en ciertas ocasiones: para afinar la puntería tirando contra un par de latas, para enseñarle a mi madre cómo disparar, para apuntarlo, un día, contra la frente de mi abuela" (22).

Aislados de todo, en un paisaje sublime, "tan vasto que empeñecía las cosas de adentro" (16) y que "hunde" a los habitantes del rancho en la tierra, la familia de este personaje sufre sus descargos e impulsos destructivos: sus juegos de caza, sus deseos de matarse, su impulsividad con las armas, pero también su indiferencia, su falta de cariño, su negación. Para Amantino, padre de dos hijos anteriores al matrimonio, a los que nunca reconoció ("no hay que andar desparramando el apellido"), los tres niños de su familia "nunca tuvieron nombre": 
Ernesto era el rengo.

Braulio, el pajero.

Mi madre, la loca. (18)

La narradora ofrece, en la página contrapuesta a ésta, una aclaración que devuelve la humanidad a estos niños estigmatizados por su propio padre:

Ernesto cojeó a partir de los cinco años, desde que tuvo polio y se le deformó la columna.

Braulio, a los seis, sufrió sus primeras convulsiones de epilepsia.

Mi madre, a los 17, creyó por primera vez que vivir no valía la pena. (19)

Todos ellos son "anormales" a los que se busca corregir. En su análisis de las formas jurídicas del siglo XIX, Foucault describe al anormal como "un monstruo cotidiano, un monstruo trivializado" (63). Menos excepcional que el monstruo, el anormal es pensado como un sujeto al que hay que corregir. Esto es lo que ocurre con Ernesto, a quien tratan, infructuosamente, de "enderezar": "El procedimiento no sirvió de mucho: al poco tiempo, volvió a doblarse" (23). La madre, afectada por sus crisis nerviosas, acude infructuosamente, durante años, a terapia, con un resultado similar: "Sentada en un sillón, en un cuarto minúsculo y mal iluminado del barrio Pocitos, mi madre repitió los mismos nombres, los mismos lugares, las mismas escenas. Durante una década, su psicóloga trató de llegar al centro de ella, pero como si fuera una fruta, no pudo hacerlo sin romperla un poco" (52).

El deseo de "enderezar" las cosas lleva a la madre a una terapia en que se encuentra con una explicación "que la marcó para siempre" (42). El médico tratante le plantea que "su angustia, así como las enfermedades de sus hermanos, habían sido causadas por el incesto de sus padres. En el fondo, le dijo, era eso: un castigo que se había autoimpuesto de forma inconsciente" (42). Este esquema de culpa y autocastigo, sin embargo, es resistido por la más joven del clan, la narradora: "Cuando me lo contó, décadas después, me pareció una idea curiosa, pero con los años noté que se había convertido en una especie de defensa y de destino, y me pareció tremendamente estúpida. Ella decía que el tema era difícil de dejar atrás y en eso sí tenía razón: sus apellidos idénticos la habían obligado a dar explicaciones durante toda su vida" (42).

La infancia y la depresión maternas son parte de la herencia de la narradora; en el penúltimo apartado del libro, más extenso que los demás, el relato es dirigido a la madre revelando este aspecto de la escritura: la pregunta sobre una anterioridad que moldea al propio yo: "A veces sospecho los destrozos subterráneos que tu angustia debe haber provocado en mí. Me digo: algo en mí debe estar dañado. Pero no, no lo distingo. Entonces, ¿dónde está, qué hice yo con todo eso?" (151), se pregunta la hija. La herencia aparece no como una elección, sino como una especie de imposición a la que se teme: "A veces sospecho que no solo mi cara es un espejo tuyo, sino que hay una parte adentro mío que también quiere imitarte, que quiere abandonarse, y no sé si esa desidia es hija tuya o mía, aunque no tenga sentido pensarlo" (151). ¿Hasta dónde, hacia atrás, se multiplican los espejos? ¿Hasta cuándo pueden seguir multiplicándose en el futuro?

Estas inquietudes, que se revelan en el último segmento de la narración, explican muchos de los fragmentos e imágenes del libro en que la narradora consulta el archivo familiar (fotos, grabaciones, objetos) con el fin de armar este puzzle de la herencia, puzzle que queda previsiblemente inconcluso ("como en el puzzle que aún no termino, me cuesta 
distinguir qué es cielo y qué es mar", 64). La tarea del recuerdo va adquiriendo una tonalidad, ya que insistentemente la hija ilumina con su memoria las escenas de lo "acostumbrado", un resignado padecimiento familiar que pone de relieve, implícitamente, las "fallas" familiares:

Me acostumbré a verla durmiendo durante el día, o despierta, como a veces se ve a los niños: con la piel de las cejas enrojecida después de haber llorado. (58)

Mi padre se acostumbró a los episodios de angustia de mi madre. Ella a los platos sucios, a las exaltaciones en público, a cierto egoísmo. Mis padres nunca andaban de la mano ni se besaban en público. (79)

Mamá, susurro de nuevo. No contesta, pero insisto. Ya me acostumbré a que se quede así, sin hablar, como si el silencio fuera otra forma del cansancio. (108, las cursivas son mías)

Tener una madre (y una herencia) es algo que se revela paulatina y lentamente. Debimos ser felices es la historia de esa lenta revelación: "Mediante gestos, yo alimentaba osos de peluche y muñecos brillantes, articulados. Con crayones azules pintaba las hojas blancas. Mecía animales de tela, muñecas de plástico negro. Entonces no podía imaginarme quién era, de verdad, mi madre. Para mí, ella se parecía a cualquier otra..."(10). Los verbos en pasado son utilizados por la voz adulta que ya sabe, que ya reconoce y procura entender aquello que la mirada infantil no sospechaba. La niñez de la narradora, descrita a través de breves viñetas, va adquiriendo progresivamente el matiz sombrío que proyecta la madre. Hay de hecho un momento muy solapado, en que se insinúa una repentina maduración de la hija. Como en muchas de las escenas narradas, la madre observa la televisión a todo volumen, olvidada de la presencia de la niña, que juega a imaginar figuras en las manchas de humedad en la pared. En el telediario informan que han encontrado a un niño que estaba perdido (una noticia que la madre sigue, porque ya antes se había aludido a su desaparición). La niña escucha lo ocurrido y algo sucede en ella: "Hallamos al niño ahogado en el arroyo Miguelete, dice el policía. Contemplo una figura en la pared. La miro desde distintos ángulos. Cierro los ojos. La miro de nuevo. Me desanimo: por primera vez no le encuentro forma de nada" (50).

Hay un antes y un después de la noticia, con la que la hija puede sentirse identificada: el muerto es un niño, como ella. ${ }^{5}$ La imaginación y el juego infantil quedan suspendidos por el impacto de esta realidad, que se acompaña de la ausencia materna: una pequeña intemperie que empuja a la madurez. El texto registra distintos momentos de este reconocimiento de la madre, de toma de conciencia de la hija. En lo que se deja entrever prácticamente como una entrevista dirigida por esta última, la madre revisa las fotografías familiares y se encuentra con una que, por su descripción, reconocemos como la portada de este libro (que se presenta, sin embargo, como "novela" y no como "autobiografía"):

Ahora mi madre, ensimismada, sostiene una foto en su mano: aparece junto a mi abuela, sentada sobre un tronco en las orillas de la playa. Yo soy una niña de dos años, con el

\footnotetext{
${ }^{5}$ En Mugre rosa las noticias televisivas cumplen una función similar: se entrevé en ellas una amenaza, por identificación con hechos siniestros en que los niños son protagonistas. Aquí es el niño ahogado en el arroyo Miguelete; en el libro de Trías, la mujer que se suicida y se lleva consigo a su hijo pequeño. En ambos casos hay una amenaza exterior, una oscuridad que ronda y pone un foco siniestro en lo que ocurre dentro de la casa, del espacio de contención, cuyo equilibrio, de todos modos, es en sí mismo muy precario.
} 
pelo húmedo y un short amarillo, que corre hacia ellas. Mi abuela me mira. Mi madre, vestida con una malla azul salpicada por las olas, parece que sonríe a la cámara.

Después, como si acabara de describir algo muy triste, me dice:

Debimos ser felices (89).

La expresión es ambigua. Se puede entender por lo menos de dos modos: "por nuestras expresiones, se ve que éramos felices" o, por el contrario, "no éramos felices, debimos haberlo sido, lo merecíamos". En cualquiera de los dos casos, el tono de la madre ensombrece el fragmento: si fuimos felices, fue efímero (o ya no lo somos), y si no fuimos felices, tampoco podemos serlo ahora. La foto descrita es, sin embargo, luminosa. Pareciera representar el tiempo del aión (Walter Kohan), tiempo del juego infantil, "marcada por una intensidad ni sucesiva ni consecutiva" (Kohan en Punte, 17), que en la novela de Trías tiene lugar también en la representación de la infancia de Mauro. La niña de dos años corre y juega en una playa que se extiende en el horizonte, bajo un cielo azul intenso. Las tres generaciones sonríen: abuela, madre, hija. Pero solo la madre mira a la cámara, como si únicamente ella estuviera consciente de ese momento, de esa porción de existencia. Ese presente dichoso, pero teñido también de sombras de la madre y de la abuela, es capturado para la posteridad por la fotografía.

La escena, que idealiza una genealogía femenina, remite a la cuestión de la maternidad. Dos referencias clásicas delimitan en el texto la experiencia materna. Una de ellas es la figura ética de Antígona, que impresiona a la madre de la narradora muy tempranamente por "la lealtad a su hermano muerto, su destino de sepultada viva" (45), a tal punto que decide estudiar para ser profesora de literatura, con una fuerte inclinación por el mundo griego (en sintonía con su propia concepción del destino). En la figura de Antígona, con la que aparentemente se produce algo más que un deslumbramiento, una identificación, se conjugan la lealtad y el sacrificio por la familia, considerada como algo sagrado, vinculada con una ley divina que se impone por sobre la ley humana. La otra referencia es el monstruoso Minotauro, hijo de una mujer, Pasífae, y del Toro de Creta, esto es, de una unión que transgrede y reúne dos órdenes distintos, el humano y el animal. La madre, nuevamente identificándose, se apropia de esta figura mítica para protagonizar una escena que la hija observa fuera de toda "costumbre", durante un viaje a Grecia que realizan juntas:

Ella mira a los ojos a un minotaturo manco. Es una bestia que durante décadas imaginó devorando jóvenes en encrucijadas y que ahora aparece frente a ella como un hombre moribundo que sostiene el cuerpo que le queda: una cabeza sin cuernos, un brazo sin mano, un pedazo de pecho roto.

La luz de la mañana, limpia y blanca, cae desde los ventanales del museo para iluminar la cara de mi madre. No estoy acostumbrada a verla bajo luces como ésta. Ella, en la soledad de la sala, contempla la figura en silencio, las curvaturas de su carne blanca.

Pobre minotauro, le tocó pagar por culpa de sus padres, dice en voz baja, y acaricia con un dedo la cicatriz de su pecho de mármol. (134, la cursiva es mía)

En este fragmento la madre aparece bajo una luz distinta a la que la hija no está "acostumbrada", como se mencionaba anteriormente. Se encuentra bajo una luz clara que la ilumina, consciente, viva. La escenificación de una anagnórisis: no es la madre la que devela su identificación con el Minotauro (hijo de una relación prohibida, de una mezcla que resulta monstruosa), sino que es la hija quien, al contar de este modo el momento, tiñe la escena de 
dramatismo e incluso de tragedia: la de una madre legendaria, única, atrapada por un discurso normalizador que la ha estigmatizado con la "culpa" de sus padres.

La historia narrada ofrece dos líneas de fuga, que rompen con las imposiciones sociales. Por un lado, hay todo un imaginario de libertad asociado a la sororidad y al matriarcado. La abuela deja el pueblo de Rivera para primero buscar refugio en Montevideo ("En el apartamento de la calle Soriano donde vivía mi madre, mi abuela fue libre por primera vez", 54) y luego en la casa de la calle Anollés, en el pueblo de Santana do Livramento, conurbano de Rivera, pero por el lado brasileño. Este país, con su lengua y costumbres, aparece de manera idealizada: es el lugar de las vacaciones, pero también de las mujeres, una especie de paraíso femenino: "En esa, la casa de la calle Anollés, la que está casi cayendose del país, es donde mi abuela vivió sola por primera vez" (34). En este lugar protegido, la abuela, la madre y las tías conversan sobre la gente que conocen: "Tengo once años y quedo fuera de todas las conversaciones, pero no tengo otra cosa que hacer, así que me siento junto a ellas" (48). Otro quiebre es, por cierto, la misma experiencia de infancia (la de madre e hija) y su rememoración, que desterritorializa y donde emerge lo no normado.

La fuerza del matriarcado es nutritiva. A diferencia de lo que ocurre en Mugre rosa, en que la maternidad aparece atravesada de múltiples tensiones, aquí se idealiza en algunas escenas, cuando a pesar de la "costumbre" de la depresión y la amenaza del suicidio, triunfan la contención, la sensación de paz que en la niña provoca escuchar el canto de su madre:

En las noches, mi madre va hasta mi cama y me acaricia la cabeza. En un susurro, como si apenas quisiera que la escuchara, me canta:

Habia una vez un lobito bueno, al que maltrataban todos los corderos.

Habia también un príncipe malo, una bruja hermosa y un pirata honrado.

Pasa si mano sobre mi oreja y siento un ruido casi marino, como una ola que vuelve a mis oídos una y otra vez.

Todas esas cosas había una vez cuando yo soñaba un mundo al revés. (24)

La canción que canta la madre invita a la niña a pensar un mundo en que los estereotipos pueden ser burlados; los que eran malos pueden ser buenos; los feos, hermosos. Como en los carnavales, se quiebran las jerarquías y se invierten los papeles, las marcas de género, el poder. En la última página de la novela, se retoma esta escena del canto y, como hace antes con otros fragmentos, la narradora ofrece una especie de texto espejo, en que "explica" o genera correspondencias con textos anteriores:

En el entresueño, a medida que su canto se va alejando, me vienen imágenes: un rebaño de ovejas correteando por una pradera; mi madre vestida de negro, peinándose un pelo largo y brillante; un hombre con un parche en el ojo que me sonríe.

En un susurro, como si apenas quisiera que la escuchara, me canta:

Todas esas cosas habia una vez cuando yo soñaba un mundo al revés. Enseguida me quedó dormida. Me gusta hacerlo así: escuchando a mi madre cantar en voz baja, con sus manos yendo y viniendo sobre mi cabeza. (154)

Las ovejas juegan, traviesas (y ya no victimizadas), la madre-bruja es hermosa y no maligna, el "pirata" que podría ser, tal vez, ese abuelo violento y loco de esta historia, ese abuelo lejano que más se acerca a la leyenda que a la memoria, aparece aquí sonriente, amable y no temible. 


\section{Conclusiones}

Los personajes infantiles de ambas novelas ponen en discusión una diversidad de cuestiones. En primer término, por la relación entre lenguaje e infancia, advertida por diversos pensadores, estas figuras inscriben un problema político. Como escribe María José Punte, no se trata tanto de su incapacidad para "ejercer la palabra", sino para "hacerlo en el espacio público, porque es el sujeto que deberá permanecer en el ámbito de lo privado durante un período establecido mientras que los adultos así lo determinen" (12). En casi toda la novela de Trías, Mauro aparece, efectivamente, confinado al departamento, u oculto por sus padres en el campo, en tanto la narradora se mueve por la peligrosa y devastada ciudad como una cazadora que debe volver con lo necesario para nutrirlo. Otro tanto ocurre con los hijos de Amantino, quienes aparecen silenciosos junto a un padre vociferante y violento, escondidos en un rancho, casi hundidos en la tierra. Unos y otros evocan el concepto que propone Eduardo Bustelo, de infancia sacer, en que el cuerpo infantil se erige como sujeto sacrificial, un cuerpo disponible, sin acceso a la ciudadanía, la voz o el reconocimiento.

Muy unida a la falta de voz se evidencia un exceso corporal: los niños "monstruosos" abundan en la literatura como si la infancia en sí misma evidenciara lo inconcebible, aquello que se desborda de la racionalidad, lo intuitivo y animal, que en el caso de Mauro se evidencia en las comparaciones explícitas o implícitas con pirañas, conejos, ratones, dinosaurios y en el libro de Lahore, en la identificación con el Minotauro, hijo monstruoso de una relación prohibida.

Finalmente, y precisamente en virtud de esa distancia con lo humano, la infancia se vuelve hermética: "Él seguía en su trance del juego, refugiado en un lugar inaccesible para mí" (198), dice uno de los pasajes de Mugre rosa. Escribe María José Punte que "los niños parecen moverse en un territorio al cual los adultos ya no tienen acceso en sentido completo, sino solo de un manera fragmentada, inestable o aleatoria (...) la carencia no radica en el infante, sino al revés, en el adulto. Esto genera una narrativa nostálgica y deseante, pero sobre todo, melancólica. Y a veces, incluso, rabiosa" (19). Es esa narrativa nostálgica la que activa la experiencia de la maternidad en la narradora de la novela de Trías, cuyo relato traspone diversas temporalidades: la de un mundo agotado y a punto de morir; la de una cotidianidad cíclica y demandante, con Mauro en el departamento; la de los propios recuerdos infantiles, episódicos y fragmentarios; el tiempo que vive Mauro con sus juegos ensimismados, tiempo del aión. Estas intensidades son evocadas también por el relato de Lahore, en una narrativa marcadamente fragmentaria, en que los dos tiempos de las infancias narradas vienen al encuentro con el presente y un diálogo entre adultas (madre e hija) que buscan comprenderse y solidarizar.

\section{Bibliografía citada}

Benjamin, Walter. 2008. El narrador. Santiago de Chile: Metales Pesados. 
Bustelo, Eduardo. 2007. El recreo de la infancia. Argumentos para otro comienzo. Buenos Aires: Ediciones Siglo XXI.

Foucault, Michel. 2000. Los anormales. Buenos Aires: FCE.

Lahore, Rafaela. 2020. Debimos ser felices. Santiago de Chile: Montacerdos.

Osorio, Camila. 2021. "Fernanda Trías: Consumimos hasta destruirnos a nosotros mismos." El País, 6 de enero, 2021. https://elpais.com/cultura/2021-01-06/fernanda-triasconsumimos-hasta-destruirnos-a-nosotros-mismos.html

Punte, María José. 2018. Topografías del estallido. Figuras de infancia en la literatura argentina. Buenos Aires: Corregidor.

Trías, Fernanda. 2020. Mugre rosa. Random House Mondadori. 